\title{
Towards a Global Natural Resource Management System to Support Sustainable Development
}

\author{
Harikrishnan Tulsidas* \\ Economic Affairs Officer, United Nations Economic Commission for Europe, Switzerland
}

Submission: March 11, 2019; Published: May 10, 2019

*Corresponding author: Harikrishnan Tulsidas, Economic Affairs Officer, UNECE, Palais des Nations, Geneva, Switzerland

Abstract

Several revolutions in the past have taken humanity progressively to an era of unlimited resource use as seen today. As the world races to consume exponentially increasing quantities of resources, the danger of hitting the carrying capacity of the planet is looming. Along with climate change, sustainable production and consumption of resources remain a major concern today. Short-term fixes and half-baked solutions will not be able to stop the slide of this linear model into total collapse. A systems approach based on the lifecycle of resource use has been well, but tools for implementing this at a ground level are lacking. A resource management system that can help transform the industry into a new template of associative value discovery, comprehensive resource recovery, circularity and zero waste is urgently required.

Keywords: Natural resources; Mining; Petroleum; Resource management; Circular economy; sustainability; Carbon neutrality; Resources efficiency; Zero waste

\section{Introduction}

Life on earth originated some four billion years ago harnessing the energy from earth's interior, transferred through geochemical reactions in the depths of oceans [1]. As the biological system evolved, some 2.5 billion years ago, a new way of sourcing energy from the sun was perfected through photosynthesis. From then onwards, and later when land-based plant evolved, the biological system used and recycled materials to build life blocks, powered through a constant flow of energy primarily from the sun. A peculiar pattern of loops and negative feedbacks kept the web of life thriving, though a few unexpected upheavals at different junctures almost wiped out the existence of life. However, life was tenuous, and it kept going on utilizing the resources of the earth, seldom breaching the system boundaries and exceeding the carrying capacities.

Humans evolved 3.5 million years ago, and several species etched their names to the grand history of life, including our species, the Homo sapiens, who entered the stage some 300,000 years ago [2]. For the most part of human history, life continued as it did since the beginning 4 billion years ago using resources in loops, chains and webs. All this started to undergo a significant change some 12,000 years ago when the sole remaining human species started massive collaborative projects to harness solar energy more efficiently by systematic agriculture [3].

Natural resources and the environment were altered and repurposed for growing selected species and breeds of plants and animals. This increased the availability of solar energy through plentiful supply, yet limited in variety. Human populations grew, and progressively the non-domesticated plant and large animal species started to get extinct. Large tracts of forests and virgin biota were cleared for monocultures needed for the humans. However, the need for resources was limited, and therefore the usage patterns largely mimicked the natural cycles or use and reuse.

Stabilizing sea levels and adoption of agriculture made the erstwhile scavengers, gatherers and hunters to settle down. Large-scale growth of city civilizations followed, powered by growing surpluses of grains. As cities and cultures spawned, resource use become intense and more systematic. City states started to metamorphose into metropolises. Global trade routes for commodities such as cotton, silk and metals began to appear.

While the agricultural revolution had independent origins in several places around the world, the next revolution that is to disrupt the life and the environment will be more localized initially. Nation-state building started around 5000 years ago, and progressively larger and larger human empires began making an appearance. It reached a maximum when the Mongolian Empire in the thirteenth century included part of Europe. This event brought the science, inventions and technology of east and the middle east, including the long-lost Greek thought and devices into the hitherto backward wilderness of Europe [4].

Europeans took this new knowledge with great enthusiasm, which eventually led to a renaissance, enlightenment, the 
scientific revolution and the ultimately the industrial revolution by the mid-eighteenth century. Even though the industrial revolution initially used hydro and wind or wood-based power, it soon enough stumbled upon the use of coal. The steam engines replaced human, and animal muscle power and large cotton and steel plants were inaugurated [5]. These industries required coal to power, but also materials like cotton, iron ore and other metals. A new era has been inaugurated, which scientists now call the Anthropocene [6].

\section{The Anthropocene and exponential increase in resource use}

Even though the starting date of the Anthropocene is being debated, there is no argument that earth-scale reengineering has now been advanced to a new level. Massive inflows of raw materials powered large-scale urbanization, also transformed agriculture from being dependent on muscle power to fossil fuel and mineral based fertilizer and pesticide inputs. Petroleum was also added into the portfolio of essential resources required to power the civilization. The world consumed approximately 59 billion tonnes of natural resources in 2005, which increased to 70 billion tonnes in 2010 and 90 billion tonnes in 2017 [7].

What is more important is the severity of environmental impact and the massive amount of wastes generated during the production of these resources. These impacts were mainly due to enormous scale mining, offshore petroleum production, refining, and the materials discarded after use. A part of the petroleum production goes into the manufacture of plastics, and production of nitrogen fertilizers, most of which ultimately ends up in the oceans, the common garbage disposal site of the world. Phosphate another agricultural input creates five to six tonnes of phosphogypsum for every tonne of phosphate fertilizer. Some of this ends up in the ocean or is stored as waste mountains. It is this resource use which has pumped out carbon dioxide into the atmosphere and raised its levels to over $410 \mathrm{ppm}$ today and has triggered a runaway global warming.

First significant recognition of exponential and unsustainable resource use, though with faulty assumptions and forecasts, was raised in 1970 [8], but it became a global concern with the presentation of the report, Our Common Future to the United Nations General Assembly in 1987 [9]. The principle of Sustainable Development came to be ingrained in our collective consciousness with this report. As a follow-up, the Millennium Development Goals (MDGs) were put into action with a limited agenda during 2000 - 2015. Some of the goals were achieved ahead of targets, but some remained unrealized as of 2015 . Moreover, the threat of climate change continued to become more serious.

In 2015, nations came together again to roll-out the most ambitious collective agenda ever, the Sustainable Development Goals (SDGs) with a broader scope and participation of all people on this planet [10]. Hinged on the triad of People - Planet - Prosperity, this new action plan puts considerable stress on making production and consumption of natural resources more responsible. Its Goal 12 call for reducing consumption by reducing, reuse and recycle and minimize waste as low as achievable. Essentially, it means resource production should try to become more efficient, reduce the environmental footprint and eliminate all wastes and embrace circularity.

This transformation, it is now being understood, requires a systems approach to resource management. This means a total break from the linear systems of produce - use - waste. Such a systems approach could make the flow of resources circular, from production through use and reuse, with awareness of the impacts on the environment, economies and societies at each stage of the lifecycle. It could be immediately recognized that such a systems approach will also have to disconnect from the high-input and high-output formula of the commodity markets.

\section{Core principles of sustainable resource management}

Resource production, the commodity markets and unbridled consumption require increasing volumes that need to double every 30 years or so. The co-generated wastes and attended environmental impacts also increase in a similar exponential fashion. If the grand objectives of 2030 agenda must be achieved in time, and within reasonable costs, then there must be a change in the fundamental principles we use to manage resources.

To say that this is just an environmental requirement is also way off the mark. Modern so-called "extractive" business is wading more and more into trouble. Market volatiles threaten financial returns to shareholders [11], rising environmental intrusions are being less tolerated [12], and there is widespread social disaffection everywhere. A viable business, even from the viewpoint of stable returns on the financial capital is becoming uncertain, needless also to say the effectiveness of returns on social and environmental capital. This an industry, which could be can be exemplified as "fragile".

However, if sustainable development must continue and strengthen, we need natural resources, albeit in a new manner. Policies on sustainability such as circularity and waste minimization are now widely recognized and adopted in national frameworks. However, plans are not translating to tangible improvements at the ground level. What is lacking are the tools that could implement a systemic approach to resource management.

Such a toolkit for sustainable resource management should be based on the core principle of "first-order negative - second-order positive" with less noticeable short-term gains, but with non-linear, exponential benefits in the longer-term. Comprehensive resource recovery, the idea that land should be disturbed minimally by recovery all possible values with a full lifecycle focus on a set of priorities should be one of the core propositions on which such a toolkit should be built. Circularity and the progress towards zero-waste are other ideas. 
The core principles also need to be associative. It should connect to all sectors of development and the eco-system by weaving a network of activities that lead to good social, environmental and economic outcomes. Profits do matter, but they should follow activities leading to improvement in the quality of living, the health of the planet and inter-generational justice. The links of resource management should always be underpinned by the Food-Water-Energy (FEW) nexus.

\section{Towards a global resource management system}

Technology is also disrupting the resource production industry in unimaginable ways - the rise of shale oil production an example. Traditional petroleum industry could have never digested the dynamics of shale oil recovery; it requires new technology, approaches and connections [13]. Shale development is now capable of keeping the oil price within a narrow band. A similar fate could be on the horizon for other resource sectors. Shale oil experience gives us room to consider double-loop learning, the art of learning and re-learning and the power of Bayesian updating.

Whatever the complexities of the resource management in future, it could be kept simple on the Occam's razor style. The endpoint, however, should always be social, environmental and economic viability. A toolkit that supports resource management of this kind should be "global workspace", a sort of universal blackboard where diverse background processes related to socio-economic, technical and level of knowledge can collide and produce workable solutions.

The United Nation which has supported the making of the 2030 Agenda, being aware of this gap and has taken definitive sets of action to produce a United Nations Resource Management System (UNRMS), which could provide the toolkit the world sorely lacks today [14]. However, development of this toolkit is not a trivial activity. It requires concerted action from many stakeholders - the governments, industry, financial institutions and the academia. The system should be developed in an open environment, without compromising any of the basic principles of sustainable development or going out only half-way to produce a cosmetic patch-up.
With the availability of such a system, the necessary toolkit for making resource production and use sustainable and responsible will be in place.

\section{Acknowledgement}

The ideas expressed in the brief paper are the result of collective thinking, experimentation and analysis of many experts, mainly associated with UNECE's Expert Group on Resource Management.

\section{References}

1. Lane $N$ (2015) The vital question: energy, evolution, and the origins of complex life. WW Norton \& Company, USA.

2. Christian D (2018) Origin story: A big history of everything. Hachette UK.

3. Jared D (1997) Guns, germs, and steel: the fates of human societies. NY: WW Norton \& Company, USA.

4. Weatherford J (2005) Genghis Khan and the making of the modern world. Broadway Books.

5. Qualman D (2019) Civilization Critical: Energy, Food, Nature, and the Future. Fernwood Publishing, Canada.

6. Lewis SL, Maslin MA (2018) The Human Planet: How We Created the Anthropocene. Pelican Books, UK.

7. IRP (2017) Assessing global resource use: A systems approach to resource efficiency and pollution reduction. A Report of the International Resource Panel. United Nations Environment Programme. Nairobi, Kenya.

8. Meadows DH, Meadows DH, Randers J, Behrens WW (1972) The limits to growth: a report to the club of Rome.

9. Brundtland GH, Khalid M, Agnelli S (1987) Our common future. New York, USA.

10. Pinker S (2019) Enlightenment now: The case for reason, science, humanism, and progress. Penguin Books, UK.

11. Norway's $\$ 1$ trillion fund to cut oil and gas investments.

12. Five Vale staff and contractors arrested after Brazil dam disaster.

13. Helm D (2017) Burn out: the endgame for fossil fuels. Yale University Press, USA.

14. Sustainable Resource Management.

This work is licensed under Creative Commons Attribution 4.0 License DOI: $10.19080 / I J E S N R .2019 .19 .556008$
Your next submission with Juniper Publishers will reach you the below assets

- Quality Editorial service

- Swift Peer Review

- Reprints availability

- E-prints Service

- Manuscript Podcast for convenient understanding

- Global attainment for your research

- Manuscript accessibility in different formats

( Pdf, E-pub, Full Text, Audio)

- Unceasing customer service

Track the below URL for one-step submission https://juniperpublishers.com/online-submission.php 